\title{
CROSS SECTIONAL STUDY ON THE ASSOCIATION OF DAILY SPIRITUAL EXPERIENCE ON MENTAL WELL BEING DURING COVID 19 AMONG THE AFRICAN STUDENTS IN INDIA
}

\author{
Sheeba Joseph \\ The Bhopal School of Social Sciences, India
}

Correspondence: sheejose03@yahoo.com

\begin{abstract}
OBJECTIVES:

The current research focussed to explore the association of daily spiritual experience on the mental well- being of international students hails from Africa and pursuing studies in various higher education institutions in India. The research also tried to explore whether age and gender plays a significant role in the mental well- being of the respondents.
\end{abstract}

\section{DESIGN:}

The study is an exploratory cross-sectional in nature. The research tool comprised of the Daily Spiritual Experience Scale (DSES) and Warwick-Edinburgh Mental Well-being Scale (WEMWBS) along with the demographic details. Post reliability and validity tests established scales are used to study the variable in the research. The data was analysed using Smart PLS SEM 3.3.2.

\section{SETTING:}

The respondents comprise of international students hails from Africa and pursuing various undergraduate, post graduate and PhD courses from various institutions at Bhopal, Delhi, Mumbai and Rajasthan in India. The respondents include a cohort of 102 respondents who gave consent to be part of the study during first week of July to first week of August 2021 and were selected through purposive sampling technique.

\section{MAIN OUTCOME MEASURES:}

The research measures the association of daily spiritual experience and mental well- being during pandemic and also the coping strategies used by the respondents.

\section{FINDINGS:}

The research report shows an insignificant relation of gender to the mental well-being whereas age reported a significant association. A significant association is reported between daily spiritual experience and mental wellbeing of the respondents amidst pandemic situation.

\section{CONCLUSION:}

Pandemic outbreaks influences the mental well-being of individuals specially when they are away from the social support system. Hence counselling services and other interventions to cater to the needs of students requires a serious deliberation at the policy level. 


\section{KEYWORDS}

mental well-being, daily spiritual experience, coping mechanism

\section{INTRODUCTION}

COVID 19 outbreak has created a havoc across the world specially students. Covid-19 has radically changed the educational landscape for millions of students in the sector of higher education around the world. The international students have their own set of unique challenges such as going back to their native country, managing financial constraints, covid management, managing daily needs, shelter are few among them. [1] The swift changes, along with the chronic stress of the pandemic, may pose mentalhealth challenges, particularly if students suffer from preexisting mental-health issues. [1] The University students are ever more recognized as a vulnerable section, suffering from higher levels of mental health issues compared to the general population. Therefore, when the nature of their educational pattern drastically changes the burden on the mental health of this community is furthers amplified. [1]

The COVID-19 pandemic has fetched the focus of mental health needs and issues of various affected populations. It is known that the prevalence of epidemics heightens or creates new stressors including fear and worry for oneself or loved ones, constraints on physical movement and social activities due to quarantine, and sudden and radical lifestyle changes. A topical review of virus outbreaks and pandemics documented stressors such as infection fears, frustration, boredom, inadequate supplies, inadequate information, financial loss, and stigma. [2]

Literatures also shows low levels of mental well-being can reduce motivation, diminish concentration and hinder academic attainment. [3] Similarly other studies reported, low levels of student mental well-being can also be a major factor in self-harm and suicide ideation [4]. Previous studies suggest that factors such as race, gender, age, and financial strain are likely associated with student mental well-being. $[5,6]$ Isolation and conflicts within the home was also reported in literature. The pandemic has profoundly changed the way of life in society, starting from the need for "social distancing" even among close relatives. [7] Students experienced the pandemic's impact worldwide, many campuses closed, while courses moved to online
Platforms. [36] A cross-sectional, nation-wide study of students in China that acute stress (34.9\%), anxiety (21.1\%) and depressive symptoms (11.0\%) were prevalent during the pandemic. Mental health problems were related to fears of being infected and having decreased social support. [37] Using the 7-item Generalized Anxiety Disorder (GAD-7) scale it was found that $24.9 \%$ of college students experienced elevated levels of anxiety because of COVID19 's impact on their academic activities, daily lives (social distancing) and economic prospects. [38]

Research on Spiritual health during COVID 19 among the higher education students showed that the following are factors regarding spiritual health of students, they are in terms of developing worship of the Creator, developing oneness with God, developing peace with God, developing joy in life, developing prayer life, developing infer peace, developing respect for others and developing kindness towards other people [35].The activities, particularly of a religious nature, made it possible to reduce the physical distances imposed by forced isolation without putting people's health at risk [8,9], helping to reduce the negative effects of isolation, particularly in older people. $[10,11]$ For many people, spiritual and religious practices give meaning, purpose and constitute a supportive community. [12,13] By spiritual needs we mean everything that refers to the need to find meaning, value in one's life, peace and a sense of connection. These needs are not necessarily exclusively religious, even those who do not have a religious faith still refer to belief systems that provide feelings of meaning and purpose [14] which in this period of the COVID-19 pandemic seem to assume a role and an even deeper meaning in relation to the bewilderment that people are confronted with in the face of such a pervasive, disruptive event creating fragility, fear and daily uncertainties.

\section{OBJECTIVES}

With this background the study tried to compare and find the divergence between daily spiritual experience and mental well-being among the students from African countries and mental well-being also across different age groups and gender. It tries to understand the challenges 
faced by the respondents and coping mechanisms adopted by them amidst this crisis situation as they are away from the family support system.

\section{RESEARCH METHODS}

Cross-sectional data were collected through web-based questionnaires from the students' hail from African countries and pursuing various undergraduate, postgraduate and PhD course from higher education institutions in India located at Bhopal, Delhi, Rajasthan and Mumbai. Purposive sampling was used to invite students to complete the questionnaires from first week of July to first week of August 2021 when the alarm for delta variant, third wave hitted India. The researcher received 110 responses and excluding the invalid and repeated entries 102 were analysed PLS SEM 3.3.2. [15]

\section{TOOLS OF DATA COLLECTION}

Standardised tools on mental well being and daily spiritual experience were administered. The tool comprised of four sections such as demographic details, mental well being, daily spiritual experience and coping strategies used to manage the life situation during pandemic. The Daily Spiritual Experience Scale (DSES) developed by [16] is a 16item self-report measure designed to assess ordinary experiences of connection with the transcendent in daily life. It includes constructs such as awe, gratitude, mercy, sense of connection with the transcendent and compassionate love. It also includes measures of awareness of discernment/inspiration and a sense of deep inner peace. The Warwick-Edinburgh Mental Well-being Scale (WEMWBS) comprises of 14 items of mental wellbeing covering subjective well-being and psychological functioning, in which all items are worded positively and address aspects of positive mental health. [17]

TABLE 1 DEMOGRAPHIC DATA OF THE RESPONDENTS

\begin{tabular}{|l|l|l|l|}
\hline SI No & \multicolumn{2}{l|}{ Frequency } & Total \\
\hline Age & $(25-40)-17$ & $(26-35)-85$ & 102 \\
\hline Gender & Males- 56 & Females- 62 & 102 \\
\hline Education & $\begin{array}{l}\text { Completed UG - 26 } \\
\text { Completed PG -22 }\end{array}$ & $\begin{array}{l}\text { Pursuing UG- 28 } \\
\text { Pursuing PG-14 } \\
\text { Pursuing PhD - 12 }\end{array}$ & 102 \\
\hline
\end{tabular}

\section{FIGURE 1 PRELIMINARY CONSTRUCT OF THE STUDY}

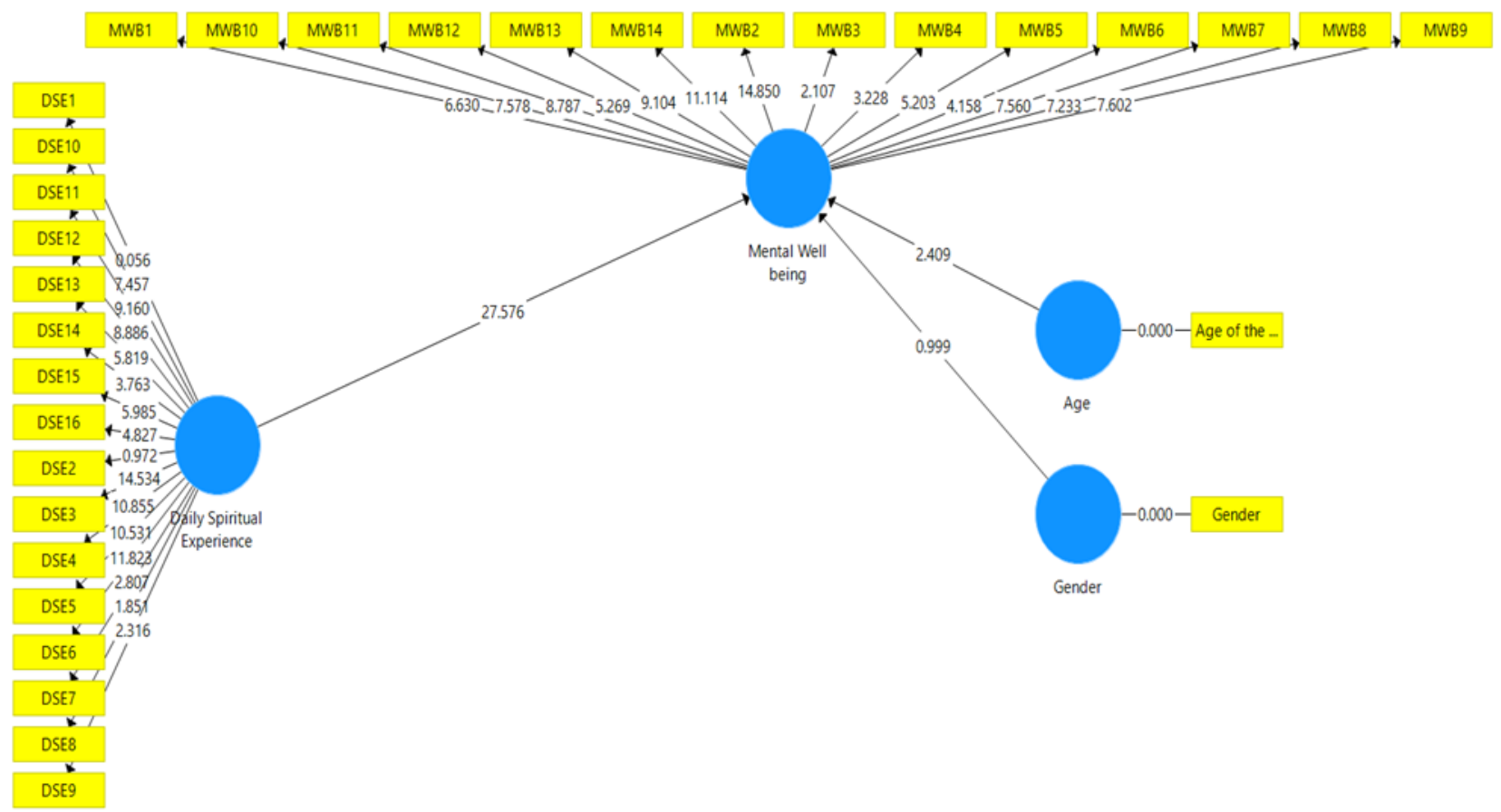




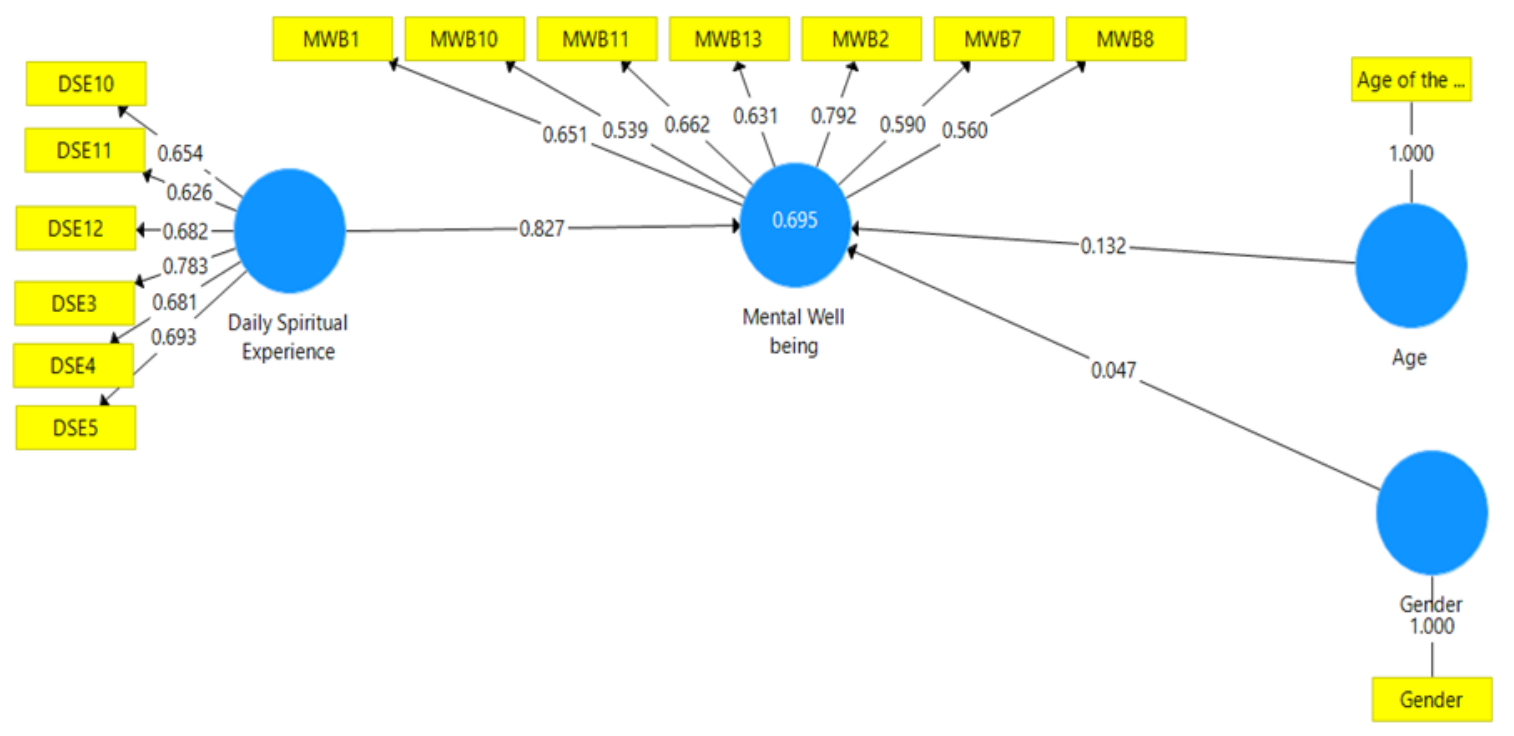

\section{HYPOTHESES}

$\mathrm{H} 1$ - Daily spiritual Experience is significantly corelated to mental well being

$\mathrm{H} 2$ - Age is significantly corelated to mental well being H3- Gender is significantly corelated to mental well being

The study is based on two constructs mental well-being and daily spiritual experience. The two constructs of the topic under studyhad a total of 30 indicators. After preliminary analysis the reliability and validity analysis items were conducted and the items with loadings $<.50$ were removed. [18]

Based on the chronbach alpha scores of MWB and DSE is greater than the threshold value of 0.7 and at the same time a closer look at other reliability analysis method pf Rho A, Composite reliability and AVE the scores are as per the stated limits as stated by Hair et al. [19] All the variables under the study met the stated criteria of acceptability. As such the constructs are meeting the reliability test and further analysis was commenced. The value as per the test of Dijkstra and Henseler's rho A are in accordance with the limit stated that is higher than 0.6. [20] As the values of AVE are under the limit generally accepted that is 0.5 the results show that convergent validity exists. Average Variance Extracted (AVE) is higher than 0.5 but we can accept 0.4 . Because Fornell and Larcker stated that if AVE is less than 0.5 , but composite reliability is higher than 0.6 , the convergent validity of the construct is still adequate. [21] The discriminant validity of the study was undertaken to analyse that the constructs under study are different from each other and on the basis of which further statistical analysis can be undertaken or not. Discriminant validity analysis was done by Fornell and Larcker criterion [21] and HTMT criterion, the results of which are presented in the tables given below. The figures showed that the constructs under study are different to each other and not overlapping.

\section{TABLE 2 RELIABILITY TEST}

\begin{tabular}{|l|l|l|l|l|}
\hline & Cronbach's Alpha & rho_A & $\begin{array}{l}\text { Composite } \\
\text { Reliability }\end{array}$ & $\begin{array}{l}\text { Average Variance } \\
\text { Extracted (AVE) }\end{array}$ \\
\hline MWB & 0.751 & 0.760 & 0.825 & 0.406 \\
\hline DSE & 0.777 & 0.782 & 0.843 & 0.474 \\
\hline
\end{tabular}




\begin{tabular}{|l|l|l|}
\hline & MWB & DSE \\
\hline MWB & 0.637 & \\
\hline DSE & 0.822 & 0.689 \\
\hline
\end{tabular}

TABLE 4: VALIDITY TEST - DISCRIMINANT ANALYSIS HTMT

\begin{tabular}{|l|l|l|}
\hline & MWB & DSE \\
\hline MWB & & \\
\hline DSE & 1.068 & \\
\hline
\end{tabular}

TABLE 5: VIF

\begin{tabular}{|l|l|}
\hline & VIF \\
\hline DSE10 & 1.610 \\
\hline DSE11 & 1.334 \\
\hline DSE12 & 1.505 \\
\hline DSE3 & 2.164 \\
\hline DSE4 & 1.616 \\
\hline DSE5 & 1.970 \\
\hline MWB1 & 1.525 \\
\hline MWB10 & 1.364 \\
\hline MWB11 & 1.461 \\
\hline MWB13 & 1.555 \\
\hline MWB2 & 1.784 \\
\hline MWB7 & 1.437 \\
\hline MWB8 & 1.456 \\
\hline
\end{tabular}

\section{TABLE 6: PATH COEFFICIENT}

\begin{tabular}{|l|l|l|l|l|l|}
\hline & $\begin{array}{l}\text { Original } \\
\text { Sample } \\
(\mathrm{O})\end{array}$ & $\begin{array}{l}\text { Sample } \\
\text { Mean } \\
(\mathrm{M})\end{array}$ & $\begin{array}{l}\text { Standard } \\
\text { Deviation } \\
(\text { STDEV })\end{array}$ & $\begin{array}{l}\text { T Statistics } \\
(\mid \mathrm{O} / \text { STDEV |) }\end{array}$ & P Values \\
\hline Age -> Mental Well being & 0.133 & 0.132 & 0.055 & 2.409 & 0.016 \\
\hline Daily Spiritual Experience -> Mental Well being & 0.820 & 0.835 & 0.03 & 27.576 & 0.000 \\
\hline Gender -> Mental Well being & 0.059 & 0.06 & 0.059 & 0.999 & 0.318 \\
\hline
\end{tabular}




\begin{tabular}{|l|l|l|l|l|l|l|}
\hline & $\begin{array}{l}\text { Original } \\
\text { Sample (O) }\end{array}$ & $\begin{array}{l}\text { Mean } \\
(\mathrm{M})\end{array}$ & $\begin{array}{l}\text { T Statistics } \\
(\mid \text { O/STDEV })\end{array}$ & $\begin{array}{l}\text { P } \\
\text { Values }\end{array}$ & $2.50 \%$ & $97.50 \%$ \\
\hline Age -> Mental Well being & 0.133 & 0.132 & 2.409 & 0.016 & 0.026 & 0.239 \\
\hline $\begin{array}{l}\text { Daily Spiritual Experience -> Mental } \\
\text { Well being }\end{array}$ & 0.82 & 0.835 & 27.576 & 0 & 0.772 & 0.891 \\
\hline Gender -> Mental Well being & 0.059 & 0.06 & 0.999 & 0.318 & -0.072 & 0.165 \\
\hline
\end{tabular}

From the table 6, it is evident that Age influences the Mental Well-being ( $\mathrm{P} \leq 0.05)$ and Daily Spiritual Experiences also effect the Mental Well-being ( $P \leq 0.05)$. In the unprecedented situation of COVID 19 Pandemic, the respondents who are away from their native place and family support system tried to find peace through spiritual experiences. Literature also supports the finding stating that students are trying to find peace through connecting with the creator [35].

TABLE 8: R2

\begin{tabular}{|l|l|l|}
\hline & R Square & R Square Adjusted \\
\hline MWB & 0.695 & 0.686 \\
\hline
\end{tabular}

TABLE 9: MODEL FIT

\begin{tabular}{|l|l|l|}
\hline & Saturated Model & Estimated Model \\
\hline SRMR & 0.10 & 0.10 \\
\hline d_ULS & 1.327 & 1.327 \\
\hline d_G & 0.518 & 0.518 \\
\hline Chi-Square & 257.815 & 257.815 \\
\hline NFI & 0.565 & 0.565 \\
\hline
\end{tabular}

A rule of thumb is that the SRMR should be less than .05 for a good fit (HU \& Bentler, 1995) [22], whereas values .05 <SRMR $\leq .10$ may be interpreted as acceptable Schermelleh et al 2003 [23]. So, the present research on the basis of previous literature accepts the SRMR value to validate the goodness of fit.

\section{COPING STRATEGIES TAKEN TO MANAGE FEAR AND ANXIETY}

The respondents shared that although counselling support was offered by the government, but they used alternative ways to manage their life in India amidst the pandemic. The respondents shared that government support was not provided to the international students from Africa in terms of supply of commodities, facilitate their travel back to native place or any enquiry to understand the needs and challenges. Nevertheless, the respondents found peace and harmony with help of peer support and maintaining interaction with family members frequently through online platform. They received help from church, family and their own community. The below given figure depicts the coping strategies used by the respondents.

FIGURE 3 COPING MECHANISMS ADOPTED BY THE RESPONDENTS TO MANAGE COVID 19 SITUATION

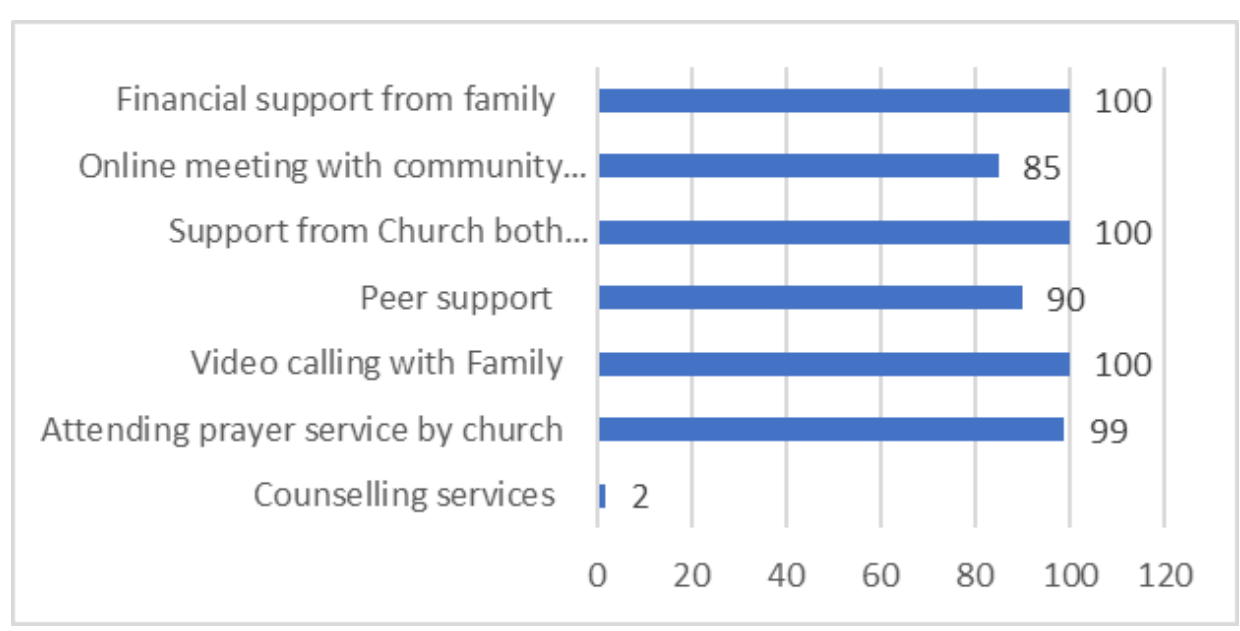


This research was carried out during the beginning of third wave alarm of delta variant in India and tried to explore how daily spiritual experience influence the mental well being of respondents who are far away from their family. The table 5 \& 6 manifested that, since the $P \leq 0.05$, Daily Spiritual experience is significantly corelated to mental well being and age is significantly corelated to mental wellbeing. Hence $\mathrm{H} 1$ and $\mathrm{H} 2$ are validated. In case of $\mathrm{H} 3$, the $\mathrm{P}$ $>.05$ the significance could not be proven. Finally, just as it was also found in the literature $[24,25,26,27,28]$ that there is a relationship between spiritual well-being and mental health. Hence the present study in in harmony with the above literatures. Mental health, on the other hand, appears to be affected to a greater extent by spiritual wellbeing and to a lesser extent by gender. These data are confirmed by previous research which highlighted how spirituality and religious practices are a protective factor and closely connected to physical and mental health. $[24,27,28]$

In this regard, the consideration of spiritual needs is necessary to provide a holistic and people-centered intervention. [29] In a certain sense it is precisely at the moment of greatest difficulty that the need for support in spiritual terms becomes stronger, in the hope of finding comfort in one's faith and beliefs. Very often, however, we are faced with inadequate preparation in responding to this type of need [30]. In fact, the importance of training health professionals so that they possess the skills to identify and support the spiritual discomfort of patients is increasingly evident. [31] A distress which can lead to suffering, a state of anguish due to not being able to feel meaning in life in particular adverse moments, which in some way undermines personal identity. [32,33]

The study also explored the coping mechanisms adopted by the respondents amid the pandemic. Central Government of India had taken many initiatives to mitigate the mental health issues of general public. However, the subjects under the study did not avail those services as they had explored many other ways to lessen the fear factor (Figure No. 3). It evinces that most of them ( $N=100)$ found respite when they were constantly in touch with their family members through video call, survived from the financial support received from their own family and the aid received from church. Attending prayer service helped the respondents a lot to revive mental well being ( $N=99)$,

support from the peer group ( $\mathrm{N}=85)$ and attending online prayer service offered by the church also facilitated internal peace and harmony $(\mathrm{N}=99)$ as reported by the respondents.

Based on the above results the research recommends the attention of government functionaries to help the international students to manage their life during crisis time. Internationalization of education which is one of the foci of NEP 2020 could be materialized effectively only by taking into account the need of foreign students. Initiatives taken at the best interest of the international students may pave way for many cross-country educational initiatives. The study also recommends to conduct an exploration on diverse areas to identify the needs and problems of students hail from other countries.

\section{CONCLUSION}

COVID 19 created a devastating condition in many parts of the world and the turmoil created affected millions. Amidst this situation all were confined to their own dwelling and disconnected with their families created discomfort, fear and stress not only because of the contagion but also due to the financial constraints and availability of commodities. Thus, the research concludes with the findings that daily spiritual experience did influence the mental well being of the respondents. Irrespective of the services rendered by various organizations, apparently individuals feel better mental well being in the strong bond with God Almighty. Age is also a significant factor which influences the mental well-being whereas gender is not playing a significant role. Addressing psychosocial and spiritual needs can really contribute to the improvement [34] in the quality of life and well-being of individuals, especially at this unprecedented time.

\section{References}

1. Browning MHEM, Larson LR, Sharaievska I, Rigolon A, McAnirlin O, Mullenbach L, et al. (2021) Psychological impacts from COVID-19 among university students: Risk factors across seven states in the United States. PLOS ONE 16(1): e0245327. https://doi.org/10.1371/journal.pone.0245327

2. Brooks SK, Webster RK, Smith LE, Woodland L, Wessely S, Greenberg N, Rubin GJ. The psychological impact of quarantine and how to reduce it: rapid review of 
the evidence. Lancet. 2020 Mar 14;395(10227):912920. doi: 10.1016/S0140-6736(20)30460-8

\section{http://europepmc.org/abstract/MED/32112714}

3. Eisenberg D, Golberstein E, Hunt JB. Mental health and academic success in college. B.E. J Econ Anal Policy. (2009) 9:1-35. doi: 10.2202/1935-1682.2191

4. Bantjes JR, Kagee A, McGowan T, Steel H. Symptoms of posttraumatic stress, depression, and anxiety as predictors of suicidal ideation among South African university students. J Am Coll Health. (2016) 64:429-37. doi: 10.1080/07448481.2016.1178120

5. Burris JL, Brechting EH, Salsman J, Carlson CR. Factors associated with the psychological well-being and distress of university students. J Am Coll Health. (2009) 57:536-44. doi: 10.3200/JACH.57.5.536-544

6. Hardeman RR, Przedworski JM, Burke SE, Burgess DJ, Phelan SM, Dovidio JF, et al. Mental well-being in first year medical students: a comparison by race and gender. J Rac Ethnic Health Disparit. (2015) 2:403-13. doi: 10.1007/s40615-015-0087-x

7. Parisi R, Lagomarsino F, Rania N, Coppola I. Women face to fear and safety devices during the COVID-19 pandemic in Italy: impact of physical distancing on individual responsibility, intimate and social relationship. Front Public Health. (2021) 9:622155. doi: 10.3389/fpubh.2021.622155

8. Koenig HG. Maintaining health and well-being by putting faith into action during the COVID-19 pandemic. J Relig Health. (2020) 59:2205-14. doi: 10.1007/s10943-020-01035-2

9. Frei-Landau R. When the going gets tough, the tough get-creative": israelijewish religious leaders find religiously innovative ways to preserve community members' sense of belonging and resilience during the COVID-19 pandemic. Psychol Trauma. (2020) 12:S258-60. doi: 10.1037/tra0000822

10. Ishikawa RZ. I may never see the ocean again: loss and grief among older adults during the COVID-19 pandemic. Psychol Trauma. (2020) 12:S85-6doi: 10.1037/tra0000695

11. Von Humboldt S, Neyda M, Mendoza-Ruvalcaba Merino EDA, Costa A, Cabras E, et al. Smart technology and the meaning in life of older adults during the COVID-19 public health emergency period: a cross-cultural qualitative study. Int Rev Psychiatr. (2020) 32:713-22. doi: $10.1080 / 09540261.2020 .1810643$
12. Gray AJ. Resilience, spirituality and health. Psyche Geloof . (2017) 28:32-40.

13. Defranza D, Lindow M, Harrison K, Mishra A, Mishra H. Religion and reactance to COVID-19 mitigation guidelines. Am Psychol. (2020). doi: 10.31234/osf.io/zvyc2. [Epub ahead of print].

14. Büssing A. Spirituality as a resource to rely on in chronic illness: the SpREUK questionnaire. Religions. (2010) 1:9-17. doi: 10.3390/rel1010009

15. Ringle, Christian M., Wende, Sven, \& Becker, JanMichael. (2015). SmartPLS 3. Bönningstedt: Smart PLS. Retrieved from https://www.smartpls.com

16. Underwood, Lynn. (2011). The Daily Spiritual Experience Scale: Overview and Results. Religions. 2. 10.3390/rel2010029.

17. Tennant, R., Hiller, L., Fishwick, R. et al. The WarwickEdinburgh Mental Well-being Scale (WEMWBS): development and UK validation. Health Qual Life Outcomes 5, 63 (2007). https://doi.org/10.1186/14777525-5-63

18. Mathuva, David. (2015). Re: What is the acceptable range for factor loading in SEM? Retrieved from: https://www.researchgate.net/post/What-is-theacceptable-range-for-factor-loading-inSEM/559bda4c614325cb078b458c/citation/download

19. 19. Hair, J. F., Black, W. C., Babin, B. J., Anderson, R. E., \& Tatham, R. L. (2009). Multivariate Data Analysis (7th ed.). Upper Saddle River, New Jersey: Pearson Education Limited.

20. Dijkstra, Theo \& Henseler, Jörg. (2015). Consistent Partial Least Squares Path Modeling. MIS Quarterly. 39. 10.25300/MISQ/2015/39.2.02.

21. Fornell C, Larcker DF 1981 J. Mark. Res. 1 39-50

22. Hu, L.-T., \&Bentler, P. M. (1995). Evaluating model fit. In R. H. Hoyle (Ed.), Structural equation modeling: Concepts, issues, and applications (pp. 76-99). Sage Publications, Inc.

23. Schermelleh-Engel, Karin \&Moosbrugger, Helfried\& Müller, Hans. (2003). Evaluating the Fit of Structural Equation Models: Tests of Significance and Descriptive Goodness-of-Fit Measures. Methods of Psychological Research Online. 8. 23-74.

24. Koenig HG. Maintaining health and well-being by putting faith into action during the COVID-19 pandemic. J Relig Health. (2020) 59:2205-14. doi: 10.1007/s10943-020-01035-2 
25. Bentzen JS. In crisis, we pray: religiosity and the COVID-19 pandemic. Cepr Discussion Paper No. DP14824. (2020). Available online at: https://ssrn.com/abstract=3615587

26. Jafari $E$, Dehshiri GR, Eskandari H, Najafi M, Heshmati R, Hoseinifar J. Spiritual well-being and mental health in university students. Procd Soc Behv. (2010) 5:147781. doi: 10.1016/j.sbspro.2010.07.311

27. Koenig H, King D, Carson VB. Hand- Book of Religion and Health 2nd ed. New York, NY: Oxford University Press (2012).

28. You S, Yoo JE, Koh Y. Religious practices and mental health outcomes among Korean adults. PersIndiv Differ. (2019) 142:7-12. doi: 10.1016/j.paid.2019.01.026

29. Johnston D, Mayers C. Spirituality: a review of how occupational therapists acknowledge. Assess and Meet Spiritual Needs. Brit J OccupTher. (2005) 68:38692. doi: $10.1177 / 030802260506800902$

30. Ellis MR, Thomlinson P. The spiritual needs and resources of hospitalized primary care patients. J Relig Health. (2013) 52:1306-18. doi: 10.1007/s10943-0129575-Z

31. Balboni MJ, Peteet JR. The relationship between medicine, spirituality and religion: three models for integration. J Relig Health. (2014) 53:1586-98. doi: 10.1007/s10943-014-9901-8

32. Timmins F, Caldeira S. Assessing the spiritual needs of patients. Nursing Standard. (2017) 31:47-53. doi: 10.7748/ns.2017.e10312

33. Caldeira S. Clinical validation of the nursing diagnosis spiritual distress in cancer patients undergoing chemotherapy. Int J Nursknowl. (2017) 28:44-52. doi: $10.1111 / 2047-3095.12105$

34. Morocutti P. Correlazioni positive traspiritualità e salute: irisultati di alcuneindagini/Positive correlations between spirituality and health: results from some surveys. Medicina E Morale. (2019) 68:41-54. doi: $10.4081 /$ mem.2019.566

35. Francis Hutabarat; Franklin Hutabarat. "Factor Analysis of Spiritual Health during Covid-19 Pandemic: A Positioning of Adventist Higher Education Institution Students in Asia-Pacific International University". European Journal of Molecular \& Clinical Medicine, 8, 2, 2021, 1283-1294. Available : https://ejmcm.com/article 7757.html (Accessed on $3 / 12 / 2021)$
36. Yong, Q. (2020, April 4). Time for universities to show their commitment to society.

https://www.universityworldnews.com/post.php?story $=20200401154815248$

37. Ma, Z., Zhao, J., Li, Y., Chen, D., Wang, T., Zhang, Z., Chen, Z., Yu, Q., Jang, J., Fan, F., Liu, X. (2020). Mental health problems and correlates among 746217 college students during the coronavirus disease 2019 outbreak in China. Epidemiology and Psychiatric Sciences, 29, Articlee181. https://doi.org/10.1017/S2045796020000931

38. Cao, W., Fang, Z., Hou, G., Han, M., Xu, X., Dong, J., Zheng, J. (2020). The psychological impact of the COVID-19 epidemic on college students in China. Psychiatry Research, 287, Article1 12934. https://doi.org/10.1016/i.psychres.2020.112934 